Pregledni znanstveni rad DOI: $10.17234 /$ Croatica.42.8

UDK: 81 '362

811.163.42’367.625:811.163.6’367.625

Primljen: 5. XII. 2017.

Prihvaćen: 19. II. 2018.

\title{
PRILOG KONTRASTIVNOJ GRAMATICI: O KATEGORIJALNOSTI GLAGOLSKOGA VIDA, VREMENA I NAČINA TE FUNKCIONALNOSTI U JEZIKU*
}

\author{
Anita Peti-Stantić \\ Filozofski fakultet Sveučilišta u Zagrebu \\ Odsjek za južnoslavenske jezike i književnosti \\ anita.peti-stantić@ffzg.hr
}

U radu se na tri specifična primjera upotrebe glagolskih konstrukcija u slovenskom i u hrvatskom raspravlja o metakognitivnim i analitičkim znanjima potrebnima za uspostavu kontrastivne gramatike bliskosrodnih jezika. Primjeri gramatičkih konstrukcija o kojima je riječ su: 1. izricanje buduće radnje prezentom nesvršenih i svršenih glagola, 2. izricanje gotove sadašnjosti i 3. izricanje imperativnosti oblicima prezenta, perfekta i futura. Analizom navedenih primjera usmjerava se pozornost na dva univerzalna lingvistička problema koja proizlaze iz organizacije jezične građe hrvatskoga i slovenskoga jezika, a o kojima treba voditi računa prilikom sastavljanja kontrastivne gramatike. Jedno je od njih pitanje tzv. pravog značenja vremenske oznake i činjenice da je značenje o kojem najčešće govorimo kao o "pravom" takvo samo sa stajališta trenutka govorenja kao sadašnjega, što treba eksplicirati u opisu, dok je drugo pitanje funkcionalnosti, shvaćene u kontekstu informacijske strukture, tj. mogućnosti izricanja odnosa prema vremenu i načinu drugačije, a ne samo glagolskim oblikom (npr. prilozima i drugim leksičko-gramatičkim sredstvima čiju ulogu tek treba istražiti).

Ključne riječi: kategorijalnost glagola, hrvatski, slovenski, funkcionalna perspektiva, informacijska struktura rečenice

\footnotetext{
* Rad je dijelom istraživanja provedenih u okviru znanstvenoga projekta Modeliranje mentalne gramatike hrvatskoga: ograničenja informacijske strukture koji financira Hrvatska zaklada za znanost pod brojem HRZZ-IP-2016-06-1210.
} 


\section{UVOD}

Usporednim proučavanjem hrvatskoga i slovenskoga jezika nije se, dakako, moguće baviti bez svijesti o njihovoj bliskosrodnosti na svim razinama, počevši od povijesno najstarije, genetske srodnosti, logično povezane s tipološkom srodnošću koja se ogleda u podudarnim obrascima jezičnoga ustrojstva, onda i do one koju možemo nazvati trajnom vrijednošću slovensko-hrvatskih odnosa, kontaktne srodnosti, koja je prije svega uvjetovana geografskim položajem i, dakako, stalnim ispreplitanjem rubnih dijalekata i susretima govornika. Za konstrastivnu je sinkronijsku jezičnu analizu od svih nabrojanih oblika srodnosti, unatoč tomu, doista relevantna jedino tipološka.

Kako je kontrastivna gramatika uvijek u odnosu prema drugoj gramatici, tumačim je polazeći od Simeonove odrednice: "Kada govorimo o kontrastu, imamo pred očima da se jedna stvar razlikuje od druge u granicama danoga funkcionalnog sustava." (Simeon 1969: 698, sub. v. kontrast). Iz toga proizlazi da za uspostavu funkcionalne kontrastivne gramatike dvaju jezika prije svega treba utvrditi tipologiju podudarnosti i tipologiju raznolikosti, zato što se tek onda može vidjeti koje sastavnice jednoga jezika ulaze u odnos sa sastavnicama drugog jezika. Tipologiju kontrastivnih oblika, dakle nepodudarnih i raznolikih odnosa, moguće je graditi samo polazeći od izvorne kompetencije u materinjem jeziku, koja se onda u procesu učenja ovjerava na gramatičkim obrascima drugog jezika.

Specifičnost odnosa bliskosrodnih jezika u procesu učenja (najkraće rečeno - razvijanja receptivnih i produktivnih sposobnosti u ciljnom jeziku) $u$ tom kontekstu prije svega vidim u visokom stupnju metakognitivne svijesti, ${ }^{1}$ tj. ne-racionalizirane svijesti o stvarnim ili pretpostavljenim podudarnostima dvaju jezika. Kako bi se postigao krajnji cilj u svladavanju drugog jezika, tj. uspostavljanje približno iste razine jezične kreativnosti u drugom jeziku kao što je ona postignuta u prvome, metakognitivnu je svijest nužno suočiti s gramatičkom sustavnošću obaju jezika. Pri tome mi se obuhvatna i dora-

\footnotetext{
Jedno od važnih pitanja koje u tako shvaćenu okviru treba postaviti, jest pitanje o tome u kojoj mjeri ta svijest olakšava, a u kojoj otežava učenje drugog jezika (L2), koje će u ovoj situaciji ostati otvoreno. Za odgovor na njega treba provesti opsežno istraživanje koje mora uključivati i psiholingvističke i sociolingvističke uvide. Drugo važno pitanje tiče se metode učenja gramatičkih obrazaca u bliskosrodnom jeziku, tj. onoga kako nam ta svijest može pomoći u potpunijem i osvještenijem svladavanju gramatike ciljnoga jezika.
} 
đena kontrastivna gramatika koja vodi računa o mnogovrsnoj raščlanjenosti suvremenih jezika čini jednim od nezaobilaznih pomagala.

U ovom ću se radu stoga, nastojeći otvoriti pitanja u tradiciji kritičkoga promišljanja o gramatičkom ustrojstvu koju je i na Filozofskom fakultetu Sveučilišta u Zagrebu, i u znatno široj okolini, tijekom čitavoga svoga radnoga vijeka promovirao profesor Ivo Pranjković, sa stajališta kontrastivne sintakse baviti tek malim brojem odabranih problema sustavnoga opisa i funkcionalnoga statusa glagolskih oblika za izricanje kategorije vremena u suvremenom slovenskom i hrvatskom jeziku.

\section{REPERTOAR(I) I UPOTREBE²}

2.1. Izricanje buduće radnje prezentom nesvršenih i svršenih glagola u slovenskom i hrvatskom jeziku

Premda po mnogim tipološkim obilježjima izrazito podudarni, slovenski se i hrvatski sustav oblika za izražavanje glagolskih vremena razlikuju po repertoaru, ali i po tipologiji upotrebe. Razlike u repertoaru najuočljivije su u izostanku posebnih aoristnih i imperfektnih oblika za izricanje prošle radnje, kao i u izostanku posebnih oblika futura II. za izricanje buduće radnje u slovenskom jeziku. ${ }^{3} \mathrm{Uz}$ ta pitanja, u kontrastivnom se suočavanju dvaju jezika pokazuju i druga, kako danas mislim, znatno zanimljivija pitanja vezana uz bitno složenije odnose između značenja i upotrebe oblika za izricanje kategorije vremena. Kako bih to oprimjerila, navest ću jednu od često ponavljanih tvrdnji - u suvremenom je standardnom slovenskom jeziku i prezentom nesvršenih, ali i prezentom svršenih glagola moguće izraziti radnju koja će se dogoditi u budućnosti. U hrvatskoj se gramatičkoj literaturi, premda rijetko, i to više u tek nekoliko specijaliziranih tekstova, nego u samim gra-

\footnotetext{
Sustav glagolskih vremena u hrvatskom jeziku pregledno prikazuje Brlobaš (2013).

Trodioba o koju se autori gramatika oslanjaju u opisu jezika, s trima osnovnim gramatičkim oznakama, sadašnjošću, prošlošću i budućnošću, funkcionira samo načelno, prije svega zato što se u realizaciji (upotrebi) svakog vremenski obilježenog glagolskog oblika uspostavlja i ostvaruje složeni odnos između vremena govorenja i vremena događanja. Dio tog odnosa je neutralan, ugrađen u jezični sustav svakog jezika. Jedan od takvih primjera je činjenica da se i u slovenskom i u hrvatskom oblicima prezenta izražava svevremenost. Takva je upotreba prezenta moguća samo pod pretpostavkom da je neku tvrdnju moguće izreći bilo kada i bilo gdje. Primjeri su poznati, slov. Zemlja se vrti okrog svoje osi, hrv. Zemlja se vrti oko svoje osi.
} 
matikama, navodi kako izricanje buduće radnje oblikom svršenoga glagola u suvremenom standardnom jeziku nije moguće, nego se radnja koja će se dogoditi u budućnosti može izraziti samo prezentom nesvršenih glagola, dok je mogućnost izricanja budućnosti prezentom svršenog glagola u hrvatskome ostvariva samo na razini stilski obilježena razgovornoga jezika. ${ }^{4}$

Upravo se Pranjković (2009: 79 i dalje), dijelom zbog svoga ranoga proučavanja djela Augusta Musića, autora vjerojatno najglasovitije rasprave o porabi perfektivnog prezenta u hrvatskom i u slovenskom jeziku, ali i zbog vlastitih interesa i istraživanja, više puta vraćao problemu prezenta svršenih glagola pa tako kaže (ibid: $80-81$ ):

Trideset tri godine poslije razmotrene objavio je Musić raspravu Slovenski efektivni prezent, kojoj pridružuje i dodatak u kojem se nažalost, kao što je već rečeno, povlači pred autoritetom Karla Brugmanna pa zajedno s njim tvrdi da je primarno značenje svršenoga prezenta uvijek futursko. Unatoč tomu što je vjerojatno da takvo tumačenje svršenoga prezenta uglavnom odgovara stanju u istočnim i zapadnim slavenskim jezicima i u slovenskom jeziku i kajkavskom narječju, uvjeren sam da to nikako ne vrijedi za hrvatski (i srpski) jezik, odnosno za štokavštinu. Štoviše, u štokavštini se svršeni prezent načelno i ne upotrebljava umjesto futura prvog (ne kaže se npr. Sutra otputujem u Opatiju, nego samo Sutra putujem u Opatiju). ${ }^{5}$

Tip primjera koji ocrtavaju fenomen i na osnovi kojih ću govoriti o kontrastivnom suodnosu upotrebe svršenog prezenta $u$ značenju futura $u$ slovenskom i hrvatskom za slovenski su sljedeći:

1.1. slov. (Popoldan) pridem na fakulteto.

'Poslijepodne dođem na fakultet.'

1.2. slov. (Popoldan) prihajam na fakulteto.

'Poslijepodne dolazim na fakultet.'

1.3. slov. (Popoldan) bom prišla na fakulteto.

'Poslijepodne ću doći na fakultet.'

4 Specifičnostima se izricanja glagolskoga vida u slavenskim jezicima, posebno s kognitivnoga stajališta, detaljno bavio Stephen Dickey (2000), a u nas u kontekstu dinamičkoga razvojnog modela o tome govore Belaj i Tanacković Faletar (2017: 37-63).

5 U fusnoti 6 na ovom mjestu se kaže: “To doduše ne znači da se svršeni prezent ne može upotrebljavati u značenju buduće radnje. Takva je budućnost međutim u pravilu obilježena kao modalna (a futur prvi označuje budućnost koja je izvjesna koliko god to budućnost može biti), što se vidi i po tome da podrazumijeva, i to nužno, modalne riječi, npr. Možda štogod ulovim za večeru” (Katičić 1986: 48). 
Iz primjera je jasno da se ostvarivanje radnje u budućnosti predviđa vremenskim prilogom koji nosi oznaku budućnosti, no na osnovi pretraživanja korpusa ${ }^{6}$ moguće je potvrditi da su i rečenice bez priloga ovjerene.

U hrvatskom će s druge strane primjeri kakvi se navode u nastavku, dakako, biti gramatični, no u rijetkim se slučajevima kad se o njima govori, na takve primjere referira kao na razgovorne, ne sasvim standardne:

\subsection{Nazovem te večeras.}

\subsection{Dođem sutra. Gdje ćeš me čekati? / Gdje me čekaš?}

Kako bi se u potpunosti razumjelo o čemu je riječ te se tek onda moglo procjenjivati točnost upravo izrečenih tvrdnji, treba znati da je $u$ standardnom hrvatskom jeziku sustav gramatičkih oznaka za izricanje kategorije vremena dopunjen oprekom po gotovosti, tako da razlikujemo:

a. sadašnjost i gotovu sadašnjost

b. prošlost i gotovu prošlost

c. budućnost i gotovu budućnost.

Premda ovdje nije moguće detaljno protumačiti svaki od potencijalno zanimljivih oblika, reći ću samo riječ-dvije o odnosu sadašnjosti i gotove sadašnjosti, koja nas sa stajališta upotrebe prezentskih oblika svršenih glagola u značenju futura najviše zanima. Sadašnjost dakle može biti apsolutna ili prava i relativna ili neprava, ovisno o tome je li radnja o kojoj je riječ u odnosu prema vremenu govorenja (tempus dicendi) ili prema vremenu o kojem se govori, vremenu događanja (tempus agendi). ${ }^{7}$ Tako su primjeri prave sadašnjosti u hrvatskom:

3.1. Imam za tebe jedno iznenađenje.

3.2. Znam to vrlo dobro.

6 Korpusi slovenskoga jezika korišteni u ovom radu su Gigafida http://www.gigafida.net/ i slWaC http://nlp.ffzg.hr/resources/corpora/slwac/, dok je za hrvatski jezik korišten korpus hrWaC http://nlp.ffzg.hr/resources/corpora/hrwac/. Kako ovdje nije riječ o korpusnom istraživanju, nego se korpusima služim tek za potvrde teorijskih teza, u radu se ne navode specifične statističke mjere.

7 "Opće je poznato da je za funkcionalnost sustava oznaka kategorije vremena relevantan odnos između vremena govorenja i vremena događanja. U svim poznatim jezicima postoji načelna univerzalija tročlanog odnosa prema vremenu govorenja, bez obzira na to kako ga se shvaća, o čemu se može i treba raspravljati, jer upravo to razumijevanje određuje aktualizaciju sustava u pojedinom jeziku. Ta se tročlanost ogleda u vremenu prije, sada (istovremeno) i poslije. Obično se s tim u vezi stoga kaže kako oznake kategorije vremena, tj. prošlost, sadašnjost i budućnost, odgovaraju osnovnom obrascu našeg snalaženja u (astronomskom) vremenu" (Barić i dr. 2007: 406). 
Primjeri neprave sadašnjosti, da se zadržimo samo na najbolje proučenima i na onima čija je gramatička oznaka prezent (premda je nepravu sadašnjost moguće izraziti i pripovjedačkim imperativom, iterativnim kondicionalom i svevremenskim imperativom) su:

a. tzv. pripovjedački ili historijski prezent

4.1. Ušavši u arkade, zapletem se i padnem.

4.2. Već se mjesec tri puta povratio, a Palunka svejednako nema.

b. tzv. futurski prezent

4.3. Sutra dolazim na ručak. (nesvršeni glagol)

4.4. Možda štogod ulovim za večeru. (svršeni glagol)

c. tzv. svevremenski prezent

4.5. Sve se može kad se hoće.

Iz navedenih je primjera jasno da i u hrvatskom prilikom ostvarivanja sustava postoji stilski neutralna mogućnost izražavanja buduće radnje prezentom svršenih glagola uz značenjski odgovarajuće priloge, no i uz one koji ne govore ništa o vremenu događanja, kao i u rečenicama bez priloga: ${ }^{8}$

5.1. Možda te (večeras) nazovem.

5.2. Nazovem te. ${ }^{9}$

5.3. Možda dođem (sutra). Gdje ćeš me čekati?/Gdje me čekaš?

5.4. Dođeš? Dođem.

Ovdje svakako treba spomenuti kako, unatoč podacima iz korpusa slovenskoga jezika u kojima je pojavljivanje prezenta svršenoga glagola za označavanje buduće radnje izrazito često, Toporišič (2004: 512) navodi kako neke slovenske gramatike smatraju upotrebu nesvršenih glagola u prezentu za izricanje budućeg vremena pogrešnom. Načelno se slaže s takvim mišljenjem i nudi rečenicu Sprosi mi to milost, da noč in dan žalujem nad svojimi grehi te tumači kako bi na tom mjestu bilo 'ispravnije' (isticanje APS) upotrijebiti futurski oblik (da bom žaloval). Unatoč tomu priznaje

8 Takvi se primjeri, doduše, ne navode u Silićevoj i Pranjkovićevoj Gramatici (2005: 191), gdje se za buduću radnju, bez dodatnoga objašnjenja, javljaju samo oblici nesvršenih glagol: Sutra rano putujemo. Dolazim za pet minuta.

9 Ovdje je, dakako, moguće povući paralelu s 'razgovorno' obilježenim izričajima kao što su: Se vidimo sutra? ili Te nazovem. s klitikom na inicijalnoj poziciji, premda smatram kako bi za status rečenica navedenih pod $5 \mathrm{u}$ jezičnom ustrojstvu, a posebno u aktualizaciji sa stajališta informacijske strukture, trebalo provesti psiholingvističko ispitivanje kojim bi se utvrdila gramatičnost i informacijska neutralnost takvih rečenica. 
kako ima i gramatičara (ne navodi koji su to) koji zamjenu futura svršenog glagola prezentom svršenog glagola označavaju kao moguću, navodeći da se korištenjem prezenta u tim slučajevima izražava namjera (To kravo prodam), dok se futurom naglašava sigurnost ostvarivanja buduće radnje (To kravo bom prodal).

U suvremenoj se lingvistici gramatičnost i eventualna funkcionalna umještenost ovakvih rečenica, ali i svih drugih oko kojih može postojati dilema, s jedne strane provjerava korpusnom analizom, a s druge psiholingvističkim ispitivanjem prilikom kojeg se s jedne strane utvrđuje gramatičnost, a s druge strane funkcionalna 'neutralnost' ili funkcionalna 'obilježenost'. Kako takva istraživanja, koliko mi je poznato, ni za hrvatski ni za slovenski nisu provedena za fenomen o kojem je ovdje riječ, ističem potrebu takvoga rada, posebno zato što se u objema gramatičkim tradicijama uvriježilo pravilo navođenja primjera čija je jedina potvrda jezični osjećaj izvornoga govornika autora gramatika. ${ }^{10}$ Jasno je da i korpusni podaci i analize psiholingvističkih istraživanja donose relevantne podatke samo kad se precizno odrede uvjeti proučavanja, no bez njih je danas nemoguće utemeljeno govoriti o opisu i jednog jezika, a još manje kontrastivno. Smatram da upravo takvi fini detalji gramatičkoga opisa, posebno kad je riječ o jezicima koji su do te mjere bliskosrodni kao što su to hrvatski i slovenski, pronalaze svoju svrhu u funkcionalnoj kontrastivnoj gramatici.

Pri tome i u vezi s upravo navedenim problemom, kao i onima koji slijede, treba reći da su autori gramatika u nas odavno svjesni razlike između složenosti morfosintaktičke strukture i izražavanja rečeničnoga značenja "različitim jezičnim sredstvima: posebnim oblicima, pojedinim riječima, pojedinim tipovima konstrukcija (sintagmema ili rečenica), odnosom među iskazima u tekstu itd." (Silić i Pranjković 2005: 281). Unatoč tomu, kako se ni u nas, kao ni u većini drugih gramatičkih tradicija, još uvijek nije uvriježilo informacijsku strukturu rečenice doista uvrštavati u gramatičko ustrojstvo, ti iskazi uglavnom ostaju na razini stilski obilježenoga, a ne strukturnoga.

10 I o tome, kao i o drugim problemima vezanima uz primjere u gramatikama, pisali su i Pranjković (2009) i Badurina i Pranjković (2016). 


\subsection{Izricanje gotove sadašnjosti u hrvatskom i slovenskom jeziku}

Drugi je primjer, koji pokazuje kako je za ozbiljnu usporedbu prije svega potrebna visoka kompetencija u materinjem jeziku, izražavanje gotove sadašnjosti, koja se u standardnom hrvatskom jeziku uopće ne izriče oblicima prezenta, nego perfekta, i to pretežito svršenih glagola, a izražava posljedicu radnje. U tom značenju perfekt nije zamjenjiv imperfektom, aoristom ni historijskim prezentom. Takvim se predikatom u obliku gramatičkoga perfekta semantički izražava apsolutna gotova sadašnjost:

6.1. To sam upamtio još kao đak. (i sada znam)

Zamijeni li se takav perfekt aoristom, njime se izriče apsolutna prošlost, a ne više apsolutna gotova sadašnjost:

\subsection{To upamtih još kao đak.}

Kako se u gramatikama slovenskoga jezika opreka po gotovosti ne spominje, a uz to ne postoje, kao što je već rečeno, posebni oblici aorista $\mathrm{i}$ imperfekta, razliku u smislu dviju navedenih hrvatskih rečenica nije moguće jednoznačno prenijeti u slovenski jezik, već ju je moguće izraziti samo proširivanjem rečenice:

7.1. slov. Tisto sem si zapomnil šele kot učenec.

7.2. slov. Tisto sem si zapomnil šele kot učenec in zdaj to vem.

Kako bi bilo sasvim jasno o koliko se složenu sustavu radi, navodim mjesto iz Hrvatske gramatike o kojem se o tome govori (Barić i dr. 2007: 407):

Raznolikost glagolskih oblika veća je od raznolikosti gramatičkih oznaka kategorije vremena. Jednim se glagolskim oblikom može izricati više vremenskih oznaka. To znači da ne postoji uzajamno jednoznačan odnos između glagolskih paradigmi i gramatičkih oznaka kategorije vremena. Važan je dakle raspored glagolskih oblika po gramatičkim oznakama kategorije vremena.

Iz navedenog je jasno da u hrvatskom jeziku postoji i da je, kao što je istaknuto u prethodnom potpoglavlju, uočen nesrazmjer između morfosintakse i semantike na rečeničnoj razini. To upućuje na nužnost sagledavanja tješnjeg suodnosa sučelja tih dviju reprezentacijskih razina, o čemu se u suvremenoj lingvistici u posljednje vrijeme puno piše (vidi Jackendoff 1972, 2002, Culicover i Jackendoff 2005, Culicover 2013, Newmeyer i Preston 2014, Peti-Stantić 2011, 2014, 2017). 
Smatram da je već i iz do sada navedenih primjera jasno kako odnos između gramatičkih oznaka kategorije vremena i upotrebe po kategoriji vremena obilježenih glagolskih oblika nije jednoznačan. Još je jasnije kako ta upotreba ni u kojem slučaju nije samo vremenski obilježena, nego je obilježena i po gotovosti koja se ostvaruje kao semantička kategorija.

\subsection{Izricanje imperativnosti oblicima prezenta, perfekta i futura u slovenskom i hrvatskom jeziku}

U ovdje navedenom kontekstu posebno je važna procjena izvora koji nam omogućuju znanje o gramatici ciljnoga, dakle slovenskoga jezika. ${ }^{11} \mathrm{Kao}$ ilustraciju važnosti toga pitanja navodim tumačenje istoga probema iz nekoliko gramatika suvremenog slovenskog jezika. Riječ je o mogućnosti da se oblicima prezenta, perfekta i futura izrazi imperativno značenje. ${ }^{12}$

U tradicionalnoj se normativnoj gramatici (Bajec, Kolarič i Rupel 1973.) navodi samo mogućnost upotrebe futura u imperativnom značenju:

\subsection{Ali boš izginil ali ne!}

8.2. Ali ne boš tiho!

U Toporišičevoj se Slovenskoj slovnici (Toporišič 2004), ${ }^{13}$ koja je po svojoj namjeri opisna i objasnidbena, no u svojoj je realizaciji mjestimično izrazito normativna, spominje mogućnost da se svim trima vremenski obilježenim oblicima (prezenta, perfekta i futura) izriče imperativno značenje:

9.1. Da mi ne pridete več pred oči!

9.2. Da si mi zginil ispred oči!

9.3. Za ušesa te bom!

11 Pregledom gramatika u obama jezicima ne može se ne primijetiti da je problemu glagolskih vremena i njihove sintakse u hrvatskome posvećena veća pozornost nego u slovenskome. Premda je o slovenskim glagolima objavljena čitava monografija (Lečić 2004), ni u njoj se ne raspravlja o suodnosu morfosintaktičkoga oblika i potencijala konceptualnoga značenja, već se detaljno navode svi morfološki oblici i vrste slovenskih glagola. To je, dakako, dobrodošla pomoć, no ne zadire u bît semantičkoga problema upotrebe glagola, a još manje pomaže prilikom zacrtavanja kontrastivne gramatike. Isto vrijedi i za Greenbergovu A Short Reference Grammar of Slovene koja je iznimno pregledna, no u njoj nema detalja ove vrste.

12 U hrvatskom su se posebnostima načina izražavanja imperativnosti recentno bavili i Pranjković i Badurina (2012) te Karlić i Klarić (2015).

13 Ta je gramatika inače poznata po tome što se u njoj navode brojne podjele (koje zapravo ne predstavljaju posebna pravila), tj. nabrajanja pojedinačnih, naizgled različitih primjera. Kad ih se detaljnije prouči, jasno je da su to slučajevi koji se sistematizacijom mogu svesti na znatno manji broj tipičnih primjera. 
U školskoj se Žagarevoj gramatici (Žagar 1996), koja je funkcionalna samo po tome što iza svake cjeline slijede vježbe, a inače u svemu potpuno slijedi Toporišičeve modele, ponavlja isti obrazac kao i u prethodnoj:

10.1. Nikamor ne greš! (Ne hodi!)

10.2. Da mi tega nisi več naredil! (Tega ne naredi več!)

10.3. Boš ti mene zafrkaval! (Ne zafrkavaj me!)

Ni u jednoj od spomenutih, a ni u gramatici za strance pisanoj za englesko govorno područje Petera Herritya (2000), koja ima intenciju biti obuhvatnom (u podnaslovu joj stoji comprehensive), no daleko je od obuhvata cjelovitosti slovenskoga jezika, nema ni spomena o razlici između smisla rečenica u kojima je u imperativnom značenju upotrijebljen prezent, perfekt ili futur. A upravo je to početni podatak koji bi morao biti relevantan za sastavljača kontrastivne gramatike. Nudim stoga primjer analize koja nedostaje.

Razlika u značenju između rečenica u kojima je imperativnost značenja jednom izrečena oblikom perfekta, drugi put oblikom imperativa, a treći put oblikom futura, iskazuje se u stupnju prijekora ili zabrane koji se tim iskazom izriče:

11.1. Da mi tega nisi več storil!

Rečenica izražava ublažen prijekor te bi na hrvatski mogla biti prevedena kao: To mi više nemoj raditi! Da mi to više nisi radio/napravio!

\subsection{Tega mi ne stori več!}

Rečenica izražava izričitu zabranu te bi na hrvatski mogla biti prevedena kao: To mi više ne radi! ili, još bolje: Ne radi mi to više.

11.3. Tega mi ne boš več storil!

Rečenica izražava zabranu s dozom prijetnje te bi na hrvatski mogla biti prevedena kao: To mi više nećeš raditi!

\section{ZAKLJUČAK}

Iz ovoga je kratkog pregleda jasno kako se u gramatičkom opisu svakog jezika, već prema gramatičkoj tradiciji koja se primjenjuje na taj jezik, kao relevantna ističu različita obilježja. U tom se kontekstu idealizirano pretpostavlja kako izvorni govornik usvaja gramatičko ustrojstvo toga jezika i kako je kompetencija koju doseže u njemu potpuna, a kreativnost korištenja usvojenih obrazaca visoka. Brojna suvremena istraživanja pokazuju da to 
nije slučaj, ni kad je riječ o izvornim govornicima, ni o govornicima drugog jezika. ${ }^{14}$ Stoga se nadam kako je ovih nekoliko primjera pomoglo osvijestiti činjenicu da smo i kao proučavatelji, a kamoli kao korisnici jezika, rijetko svjesni svih pretpostavki ugrađenih u funkcioniranje gramatike nekog jezika, da ne govorimo o stilskoj rezervi i stilskoj obilježenosti ili, rječnikom suvremene lingvistike, o informacijskoj strukturi rečenice. U ovom se radu nastojalo istaknuti dva univerzalna jezična problema koja proizlaze iz organizacije jezične građe hrvatskoga i slovenskoga jezika, a o kojima treba voditi računa posebno prilikom analize i posebno sastavljanja kontrastivne gramatike: 1. pitanje tzv. pravog značenja vremenske oznake i činjenice da je značenje o kojem najčešće govorimo kao o 'pravom' takvo samo sa stajališta trenutka govorenja kao sadašnjega, što treba eksplicirati u opisu; 2. pitanje funkcionalnosti, shvaćene u kontekstu informacijske strukture, tj. mogućnosti izricanja odnosa prema vremenu i načinu drugačije, a ne samo glagolskim oblikom (npr. prilozima i drugim leksičko-gramatičkim sredstvima čiju ulogu tek treba istražiti).

\section{LITERATURA}

Badurina, Lada i Ivo Pranjković. 2016. Gramatika u kontekstu: o primjerima u hrvatskim gramatikama. Hrvatski slavistički kongres 6. Zagreb: Hrvatsko filološko društvo. 241-248.

Bajec, Anton, Rudolf Kolarič i Rudolf Rupel. 1973. Slovenska slovnica. Ljubljana: Državna založba Slovenije.

Barić, Eugenija i sur. 2007. Hrvatska gramatika. Zagreb: Školska knjiga.

Belaj, Branimir i Goran Tanacković Faletar. 2017. Kognitivna gramatika hrvatskoga jezika. Knjiga druga. Sintaksa jednostavne rečenice. Zagreb: Disput.

Brlobaš, Željka. 2013. Sustav glagolskih vremena u hrvatskome jeziku. Vrijeme $u$ jeziku - Nulti stupanj pisma, Zbornik radova 41. seminara Zagrebačke slavističke škole (ur. T. Pišković, T. Vuković), Zagreb: Filozofski fakultet Sveučilišta u Zagrebu (Zagrebačka slavistička škola). 43-73.

Culicover, Peter W. i Ray Jackendoff. 2005. Simpler Syntax. Oxford University Press.

Culicover, Peter W. 2013. Grammar and Complexity: Language at the Intersection of Competence and Performance. Oxford University Press.

Dąbrowska, Eva. 2012. Different speakers, different grammars: Individual differences in native language attainment. Keynote epistemological article. Linguistic Approaches to Bilingualism 2;3. John Benjamins. 219-253.

\footnotetext{
14 Vidi npr. Dąbrowska 2012.
} 
Dickey, Stephen M. 2000. Parameters of Slavic Aspect: A Cognitive Approach. Stanford: CSLI.

Greenberg, Marc L. 2008. A Short Reference Grammar of Slovene. LINCOM Studies in Slavic Linguistics 30. München: LINCOM:

Herrity, Peter. 2000. Slovene: a comprehensive grammar. London and New York: Routledge.

Jackendoff, Ray. 1972. Semantic Interpretation in Generative Grammar. Current Studies in Linguistics. Cambrigde, Massachusetts, London, England: The MIT Press.

Jackendoff, Ray. 2002. Foundations of Language: Brain, Meaning, Grammar, Evolution. Oxford University Press.

Karlić, Virna i Kornelija Klarić. 2015. Sredstva i načini izražavanja imperativnosti: pragmatička perspektiva. "Filološke studije", Sv. 13, br. 2. 327-342.

Katičić, Radoslav. 1986. Sintaksa hrvatskoga književnog jezika: nacrt za gramatiku. Zagreb: Jugoslavenska akademija znanosti i umjetnosti, Globus.

Lečić, Rada. 2004. Slovenski glagol/Slovene verb. Oblikoslovni priročnih in slovar slovenskih glagolov/A morphological manual and dictionary of Slovene verbs. Ljubljana: Založba ZRC SAZU.

Newmeyer, Frederick J. i Laurel B. Preston. (ur.) 2014. Measuring Grammatical Complexity. Oxford University Press.

Peti-Stantić, Anita. 2011. Informacijska struktura između jezika i stila. Simpozij u spomen na Ivana Ivasa (1953.-2006.). Zagreb: Odsjek za fonetiku.

Peti-Stantić, Anita. 2014. Informacijska struktura rečenice i fonološko-sintaktičko sučelje. "Rasprave Instituta za hrvatski jezik i jezikoslovlje" (1331-6745) 39, 2, 557-580.

Peti-Stantić, Anita. 2015. How much Grammar is needed in Lexicon? Slovnica in slovar: aktualni jezikovni opis/Grammar and Dictionary: Current language description. ur. Mojca Smolej. Ljubljana: Center za slovenščino kot drugi/tuji jezik, Filozofska fakulteta v Ljubljani. 569-577.

Peti-Stantić, Anita. 2017. Od informacije do strukture i natrag: potencija i realizacija. izlaganje na: LinguaDOC I. znanstveni skup doktoranada HDPL-a: Istraživanje - od zamisli do objave. Rijeka, 25. 11. 2017.

Pranjković, Ivo. 2009. Prezent u hrvatskome standardnom jeziku i slovenski efektivni prezent. Treći hrvatsko-slovenski slavistički skup (Tretje hrvaško-slovensko slavistično srečanje): Zbornik referata s Trećega hrvatsko-slovenskoga slavističkoga skupa održanog u Opatiji 7. i 8. travnja 2006. (ur. A. Peti-Stantić). Zagreb: FF press, 79-84.

Pranjković, Ivo, i Lada Badurina. 2012. Načini izražavanja imperativnosti. Bosanskohercegovački slavistički kongres I: Zbornik radova (knjiga 1). Sarajevo: Slavistički komitet. 619-628.

Silić, Josip i Ivo Pranjković. 2007. Gramatika hrvatskoga jezika za gimnazije i visoka učilišta. Zagreb: Školska knjiga.

Simeon, Rikard. 1969. Enciklopedijski rječnik lingvističkih naziva na 8 jezika: hrvatsko-srpski, latinski, ruski, njemački, engleski, francuski, talijanski, španjolski I-II. Zagreb: Matica hrvatska.

Toporišič, Jože. 2004. Slovenska slovnica. Maribor: Založba obzorja.

Žagar, France. 1996. Slovenska slovnica in jezikovna vadnica. Maribor: Založba obzorja. 


\section{ELEKTRONSKI IZVORI}

Gigafida: http://www.gigafida.net/

hrWaC: http://nlp.ffzg.hr/resources/corpora/hrwac/

slWaC: http://nlp.ffzg.hr/resources/corpora/slwac/

\section{SUMMARY \\ A CONTRIBUTION TO CONTRASTIVE GRAMMAR: \\ ON THE CATEGORIALITY OF VERBAL ASPECT, TENSE, AND MOOD, AS WELL AS ON FUNCTIONALITY IN LANGUAGE}

This study investigates three distinct examples of the usage of verbal constructions in Slovenian and Croatian and offers an analysis of the metacognitive and analytic knowledge needed for the systematic development of a contrastive grammar of closely related languages. These grammatical constructions are: 1. the expression of future actions with the present tense of imperfective and perfective verbs, 2. the expression of the completed present and 3. the expression of imperative meaning with present, perfect, and future forms. An analysis of these examples points to two universal linguistic problems resulting from the organization of Slovene and Croatian languages. The first of these is the question of the so-called true meaning of any tense markers and the fact that the meaning usually seen as the 'real' one is not absolute, but actually depends on the speaker's perspective from the present moment of speaking, which should be made explicit in any description. The second problem is the question of functionality, understood in the context of information structure, i.e. the possibility of expressing the relation to tense and mood in some other way, not only by means of verbal morphology (e.g., through adverbs or other lexico-grammatical means whose role remains to be investigated).

Key words: categoriality in verbs, Croatian, Slovenian, functional perspective, information structure 